\title{
Александра Колаковић
}

\section{Слика Кине међу Србима: од Мао Цедунга до „челичног пријатељства"*}

\begin{abstract}
$A \bar{u} c \bar{u} p a \kappa \bar{u}$
Коришћењем изворних текстова (књига, штампе и других публикација), као и савремене литературе, како би се истражило ко, зашто и како ствара слику gруі̄ō̄a, рад има за циљ да анализира развој перцепције Кине међу Србима од периода развоја модерне српске државности до 21. века и појаве наратива о „челичном пријатељству”. Истраживања јавног мњења, која је у периоду од 2015. до 2019. године спровео Институт за политичке студије, такође су коришћена, како би се објаснила актуелна перцепција Кине. Рад настоји да изложи контуре и историчност слике Кине међу Србима, као и преношење идејних трансфера, с намером да подстакне истраживаче да посвете више пажње оваквим анализама, које би омогућиле како разумевање историје дипломатских односа Кине и Србије (у прошлости и Југославије), а истовремено и предвиђање даљих токова развоја билатералних односа.
\end{abstract}

\section{Кљуине речи:}

Кина, Кинези, Србија, Срби, слика другога, „челично пријатељство”

Представе о великим силама кроз српску историју настајале су и мењале свој облик у складу са борбом за стварање независне националне државе, изградњом демократског и парламентарног политичког поретка, променама политичких система, као и глобалним променама, а посебно онима на позицијама светске моћи. Поред наведеног, не смемо изоставити сложен економски, друштвени и културни развој, као и општи

Рад је настао као резултат активности аутора на пројектима Института за политичке студије. 
развој науке, технике и глобалне промене које су утицале на перцепције gруі̄ō̄a у српском друштву (Lyotar, 1984, p. 24; Derrida, 1992, p. 129; Todorov, 1994; Goldsworthy, 1998; Стојановић, 1999; Nors, 1999). Све наведено одразило се и на представу Кине и кинеског народа међу Србима. Поменута истраживачка тема захтева комплексна, вишегодишња и мултиперспективна истраживања, стога се овај рад ограничава да изложи контуре и историчност слике Кине међу Србима, с намером да подстакне нова истраживања. Слика Кине међу Србима веома је битна не само због успона моћи Кине, већ олакшава и разумевање променљивих односа кроз историју дипломатских односа две државе (као и у прошлости Кине и Југославије), а истовремено помаже у предвиђању даљег развоја билатералних односа.

Срби су у периоду изградње модерне српске државности (19. век) посредно преко великих култура - руске, централноевропских и западних, као и путовања, пре свега у Русију, стицали сазнања о далекој цивилизацији на Истоку и Кини. Прве информације биле су између имагинације, фантазије, бајке и реалних представа. Значајан искорак у стицању објективних информација начињен је крајем 19. века. Тада је Милан Јовановић Морски, лекар и светски путник, након повратка са путовања по Истоку, објавио књигу путописног карактера Тамо амо йо Истиоку (Јовановић, 1894; Јовановић, 1895). Географске карактеристике Кине, клима, обичаји, храна, карактерне и физичке особине људи, положај жена, цене разних производа, свакодневни живот у Шангају, Хонг Конгу и другим градовима и местима, уз компарације са Србима, добро познатим Османским царством, Турцима, као и боље познатим (у односу на Кинезе) Арапима, Морски је унео као прве јасније слике Кине и Кинеза међу Србе. Морског је у опису својих путовања следио Стеван Станишић у делу Пуйниике ириее: сибирском железницом на Далеки исиок (Маниурuја - Кина) (Станишић, 1905). Касније су и други путници, авантуристи, морепловци са Балкана писали о Кини, као на пример Милутин Велимировић у Кроз Кину: йуйойис (Велимировић, 1930). Повремено су се информације увећавале не само захваљујући популарности путописа, интересовању за далеко и егзотично, већ и услед развоја и доступности информација путем штампе (Пушић, 2006). Интересовали су се Срби и за прозу која је имала дух Кине (Бредов, 1908; Суботић, 1921).

Јачање социјалистичких идеја у Европи и свету упоредо су утицале и на идеолошка интересовања, посебно од 1921. године и оснивања Комунистичке партије Кине, а велику улогу у посредовању информацијама на линији Кина - Србија имала је Москва. Такође, уметничка инспирација, као културолошки фактор и светски ратови, као политичко-економско одређујући фактор света 20. века, утицали су да се у 
спољнополитичким рубрикама српске (југословенске) штампе перманентно увећава број информација. За идеолошки трансфер посебно је значајно да су се на српском језику појавиле књиге Револуција у Кини, утицајног марксисте и комунистичког лидера Карла Радека (Радек, 1926), док су књиге Кина (објављена као део збирке Источни народи) Живка Петковића и Савремена Кина као држава Јована Ђорђевића, доктора права са Сорбоне (Петковић, 1937; Ђорђевић 1937) пружиле стручне погледе на културу и политичке прилике у Кини. Важно је нагласити да је часопис Жена gанас у предвечерје Другог светског рата учестало писао о Кини и Кинезима. Читаоци су могли да спознају кинеско образовање, уметност („Кинеска уметност за време рата”) и обичаје („Свадбени обичаји у Кини"), као и да прочитају више о положају жена и савременој Кини у текстовима и књизи Агнес Смедли, америчке новинарке и активисткиње за права жена и ослобођење Индије од Велике Британије. ${ }^{1}$ Објашњење је у чињеници да је Женски свей, чија је прва уредница била Радмила Димитријевић, основан 1936. године на иницијативу Комунистичке партије Југославије у илегали као феминистичко гласило леве оријентације с јасним еманципаторским циљем и идеолошки прожет комунистичким идејама. Да се пред Други светски рат у Србији под утицајем Комунистичке партије ширила мисао о кинеском комунизму сведоче и књиге: Кина у йламену: савремени ироолеми Делекої исииока аутора Фјодора Махина (члана КПЈ, учесника НОБ-а и генерала Југословенске армије), Нарояна ирросветиа у Кини (књига публикована у оквиру едиције Будућност, уз превод Митре Митровић) и Кина из пера Агнес Смедли (Махин, 1939; Чугујев и сар., 1939; Смедли, 1940).

Кроз 20. век са изазовима два светска рата, као и бројним идејама и идеологијама, геополитичким променама и пројектима настајања и нестајања југословенске државе мењале су се и српске перцепције великих сила. Након Другог светског рата, Информбиро, хладноратовски сукоби и поделе, а касније детант (1972) и пад комунизма уткани су у дуготрајне процесе формирања представа о Истоку и Западу. За кинеско-српске односе и перцепције Кине међу Србима, поред постојања доминантне представе Кине оличене у биографији Мао Цедунга, у другој половини 20. века битан је однос између две комунистичке партије, односи са Совјетским Савезом, отварање према Западу, идеје Покрета несврстаних

Агнес Смедли, „Кина у одбрани независности и слободе”, Жена gанас, бр. 8. (новембар 1937), стр. 12-14; Агнес Смедли, „Писма из Кине”, Жена gанас, бр. 10 (фебруар 1938), стр. 4; Душанка Сретеновић, „Свадбени обичаји у Кини”, Жена gанас, бр. 1112 (март - април 1938), стр. 5-6; „Кинеска уметност за време рата”, Жена gанас, бр. 20 (март 1939), стр. 19; „Кина има у плану да сагради 36 земљорадничких школа”, Жена gанас, бр. 23 (јули 1939), стр. 18. 
и, наравно, нешто што је у досадашњим проучавањима недовољно истражено - идејни трансфер (директна или измењена преузимања, критике и дискусије о проблемима, искуствима и решењима кинеских комуниста). У овом контексту интересантна је 1947. година, време југословенског признања Републике Кине и посета кинеских комуниста Југославији. Планирано је тада и да Владимир Дедијер посети Кину у јануару 1948. године и напише књигу о Кинеској револуцији. Идеја је, на основу истраживања Јована Чавошког, потекла лично од Тита, који је сматрао да се о Кинеској револуцији мало пише. Очигледно је Дедијер био погодна личност за продубљивање контаката јер га је препоручивало познанство са Дунга Бивуом (Dong Biwu), чланом Политбироа Комунистичке партије Кине од времена Основачке конференције Организације уједињених нација у Сан Франциску (1945), као и контакт који су одржавали - размењивали реферате, Меморандуме својих комунистичких партија, пласирали информације у штампу (Чавошки, 2006, стр. 195199). Ипак, заокрет у југословенско-совјетским односима осујетио је планове да Дедијер стигне до Кине. Ова заборављена епизода сведочанство је колико су били компликовани односи након 1945. године између комунистичких партија и колико су као такви били погодни за изграђивање површних представа о Кини и кинеском народу, услед чега је Мао Цедунг, и поред богатства цивилизације и интеракције, остао до почетка 21. века доминантан симбол српске перцепције Кине.

Оцене југословенских (српских) интелектуалаца о Кини и 1953. године су у контексту југословенског наратива комунизма и сукоба са Русима, али и успостављања дипломатских односа 1954/55. године (Чавошки, 2013). У складу са поменутим наглашава се да је у овом периоду „мало међународних питања која интересују нашу јавност као што је склоп питања о Народној Републици Кини, о њеној унутрашњој и спољашњој политици" (Теслић, 1953, стр. 3). Интересовања јавности и наравно државног (партијског) врха у Југославији су да се добију одговори на питања: „Куда и којим ће путем Кина? Какви су њени односи са СССР? Да ли има снаге да очува независност и да спроведе револуцију до краја или ће се потчинити СССР?". Одговоре на ова питања настојао је да пружи и Владо Теслић у књизи Кинеска револуција и Москва, на чијој корици доминира слика Мао Цедунга. Он пише да је тадашња југословенска јавност са огромним симпатијама пратила „победнички ток Кинеске револуције" (Теслић, 1953, стр. 5). Значајно је истаћи да се примећује настојање да се пронађу сличности код комунистичких ставова и погледа у Кини и Југославији повлачењем паралели две револуције. „Кинеска револуција, иако на огромној просторној удаљености и са својим посебним специфичностима, у својој основи (је) врло слична 
и врло блиска нашој револуцији", пише Теслић и наглашава однос: народна власт и народна армија у терминолошком револуционарном контексту. Ипак, кључно је било нагласити однос између комунистичких партија: „наши су људи осећали да је Кинеска револуција, као и наша, морала да издржи борбу и против једног неочекиваног и подмуклог непријатеља - московског империјализма, камуфлираног под плаштом социјализма, ништа мање непријатељског од осталих" (Теслић, 1953, стр. 6).

Пред крај седме деценије 20. века може се уочити ново интересовање за Комунистичку партију Кине код српских (југословенских) интелектуалаца, што је очекивано уколико се имају у виду и промене у Комунистичкој партији Кине (односи интелектуалаца и Мао Цедунга, „Велики скок напред” 1958-1961, „Велика културна револуција” 19661976) (Чавошки, 2008, стр. 113-136). Поред књиге КП Кине и ирробле-

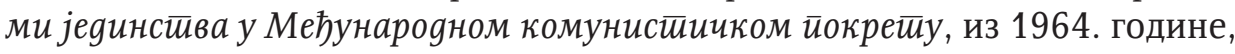
којом се посеб́о анализира однос Москве и Пекинга, вреди поменути овом приликом још две студије. Предраг Раденковић је објавио сту-

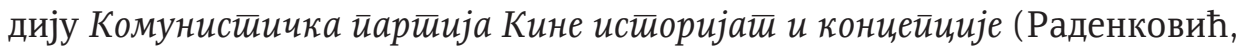
1967). Јован Динић и Душан Лазић објавили су анализе концепција и политичких пракси у унутрашњој и спољној политици Кине. Реч је о

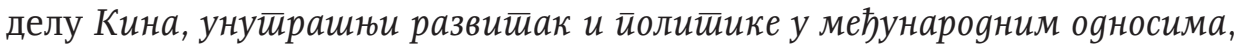
у коме су у уводној студији нагласили да је актуелност тема којима су се посветили вишеструка, са чиме се и са данашње дистанце можемо сложити. А аутори су тада образложили: „Питања унутрашњег економског и политичког развоја социјалистичких земаља доминантна су у међународном радничком покрету исто тако као што су необично значајни проблеми међународне активности социјалистичких држава. Сукоб Кине са Совјетским Савезом мада неодвојивих међународних односа у целини, од посеб́н је важности за социјалистичке снаге у свету, јер се у томе спору једним делом испољавају и различитости свих социјализама" (Динић и сар., 1970, стр. 9). Упоредо са поменутим, у тадашњој Југославији превођена су дела Мао Цедунга, штампане песме и цитати (Цедунг, 1968; Cedung, 1972).

Слика gруі̄ō̄a у српском друштву развијала се и мењала и данас садржи у себи све елементе историјске поуке и културе сећања. У време након 1980. и у задњој деценији 20. века међу интелектуалцима, а делом и у јавности, питање проучавања Кине није наилазило на велика интересовања, чему сведочи анализа књижног фонда на српском језику у Народној библиотеци Србије. ${ }^{2}$ Тек је на прелазу из 20. у 21. век, а посебно

Од 3.794 дела која су посвећена Кини (монографије, лепа књижевност, путописи, проза, поезија и сл) у оквиру базе COBIIS у периоду 1980. до 2000. године, а од овог 
у другој деценији 21. века, са јачањем моћи Кине, али и са српским економским и политичким везивањем за Кину, увећан број тема и истраживача (Симић, 2003). У овом контексту, не занемарујући историчност односа Кине и Србије (Југославије) у контексту комунистичких партија, ипак је у 21. веку актуелни однос Срба према Истоку и Западу пресудно детерминисан догађајима из најближе савремене историје. Дакле, распад Југославије, политичко приближавање две земље и НАТО бомбардовање (1999), страдање амбасаде НР Кине у Београду, граде нову и актуелну представу Кине међу Србима.

Док је један од првих корака ка интензивирању кинеско-српских односа учињен 2009. године, када је потписан Споразум о економској и техничкој сарадњи у инфраструктурним пројектима, као и платформе 16 плус 1 (Кина и 16 земаља централне и источне Европе), истраживање које је спроведено у Србији током 2008. и 2009. године показује да у овом периоду постоје одређени стереотипи према Кини и Кинезима. Уочене су две врсте стереотипа: представе о Кинезима који су се настанили у Србији од краја 20. века и према Кини и кинеском друштву у целини. Пресудан утицај код младих на стварање представе о Кини и Кинезима имају Кинези који живе у Србији, док су код старијих асоцијације на Кину засноване на култури, уметности и цивилизацији (Марко Поло, Мао Цедунг, кинеске династије, будизам и сл). Значајан број асоцијација односи се на бројност популације и територијално пространство, као и на јачање политичке позиције у свету и пандана Кине глобалној доминацији САД (Благојевић, 2009, стр. 60).

Истовремено, слика другога и перцепција Кине је и у корелацији са настојањима Србије почетком 21. века да се укључи у евроинтеграције. Анализе резултата истраживања Института за политичке студије (2015-2018) показују налазе који се тичу оцене и мишљења грађана Србије према Кини. ${ }^{3}$ Можемо пратити да је 2015 . године веома повољно мишљење о Кини имало $31 \%$ испитаника, односно повољно $26,4 \%$, док

броја 12 је стручних чланака, 5 поглавља у монографијама, два прегледна научна чланка, три кратка научна чланка и две одреднице у лексикону и/или енциклопедији. У периоду од 2000. до 2021. године штампано је 67 изворних научних чланака, 30 научних чланака прегледног карактера, 64 стручна чланка, а 27 одредница у лексиконима и/или енциклопедијама.

Истираживање јавногі мњења, Институт за политичке студије, Београд, 2015, рађено од 16. до 26. новембра; Истираживање јавноі мњења, Институт за политичке студије, Београд, 2016, рађено од 20. до 30. новембра; Исираживање јавної мњења, Институт за политичке студије, Београд, 2017, рађено од 25. маја до 5. јуна; Истираживање јавноі̄ мњења, Институт за политичке студије, Београд, 2017, рађено од 20. до 30. новембра; Истираживање јавної мњења, Институт за политичке студије, Београд, 2018, рађено од 16. до 26. maја. 
је $4,3 \%$ испитаника имало веома неповољно и $8,7 \%$ неповољно. Слични подаци су и за 2016. годину (30\% веома повољно мишљење о Кини, као и повољно $26,1 \%$, док је 4,3\% веома неповољног мишљења и $9 \%$ неповољног). За 2016. годину имамо и оцене поступака Кине који су означени као веома повољни $22,2 \%$ и повољни $31,1 \%$, док је $2,5 \%$ испитаника имало веома негативну оцену и $9,5 \%$ негативну. Децембра 2017. године бележи се благи пад веома повољног мишљења о Кини и износи 27,5\%, док је повољно мишљење присутно код $26,1 \%$ испитаника. Веома негативно мишљење о Кини дели 4,8\% и негативно 8,8\%, што су незнатна одступања у односу на 2016. и 2015. годину. Када је реч о оцени поступака Кине 2017. године веома повољно их је оценило $25,1 \%$ испитаника и $26,3 \%$ повољно, док је веома неповољно 3,8\% и неповољно 9,9\%. У 2018. години долази до пораста веома позитивног мишљења о Кини 33,8\%, повољног $24 \%$, док је веома неповољно $3,9 \%$ и неповољно $8,9 \%$. Када је реч о оцени поступака Кине, веома повољну оцену износи $26,8 \%$, повољну $27,7 \%$, док веома неповољну има 3,5\% испитаника и неповољну $8,8 \%$. Када се посматра контекст политичких, економских и безбедносних алтернатива Србије у процесу њених међународних интеграција и сарадње са другим државама (Евроазијски савез, Русија, Кина), а у односу на оне који се често у јавном дискурсу Србије одређују безалтернативним, истраживања Драгана Траиловића показују да већина грађана када је реч о учлањењу у Европску унију оптира за учлањење, али подршка не прелази $50 \%$. Када је реч о политичком и војном, међутим, већина грађана оптира за Евроазијски савез. Показало се и да углавном већи проценат грађана има веома позитивно мишљење о Евроазијском савезу у односу на Европску унију, односно веома негативно мишљење о ЕУ у односу на Евроазијски савез. Међутим, то је веома мали проценат грађана који се овако изјаснио, док је углавном највећи проценат њих и када је реч о Евроазијском савезу и када је реч о ЕУ бирао средњу опцију на скали од један до пет, са благо већим процентом оних који предност дају Евроазијском савезу. Такође, налази показују да највећи проценат грађана има веома или претежно позитивно мишљење о Русији и Кини, а и већина грађана сматра да ове две земље имају позитиван утицај на положај Србије у свету (Траиловић, 2018, стр. 41-56).

Измењена и нова улога Кине у глобалним односима и посебно у Европи (Арежина, 2018; Траиловић, 2019) последњих деценија рефлектује се и на ставове српског друштва према Кини. Овај тренд прати и званична актуелна политика Србије према Кини. Кина као једна од чланица Савета безбедности које нису признале Косово* веома је битна чињеница у креирању перцепција Срба. Оно што у српској јавности одређује овакве представе Кине јесте свест о узлазној путањи утицаја Кине у међународним 
односима, позиција суперсила, увећање броја истраживача који се баве кинеско-српским односима, а из српске перспективе важни су и економско-политички односи. Слика Кине у српској јавности се позитивно развија захваљујући континуираном присуству у медијима преко пројеката у последњих неколико година. ${ }^{4}$

Карактеристика нове перцепције Кине међу Србима, поред јачања политичких и економских веза, јесте увођење у јавни дискурс новог појма - челичноі йријаиеељсиива. Најприсутнији у јавности је био од марта 2020. године када је дошло до пандемије корона вируса и када је Кина слањем помоћи Србији, медицинске опреме, а касније уговарањем вакцина којима је вакцинисано највише грађана Србије, сликом највиших српских званичника и кинеске амбасадорке како дочекују медицинску помоћ и касније вакцине. ${ }^{5}$ Тзв. вакцина или корона медицинска дипло-

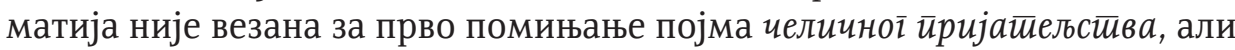
јесте утицала на веће присуство у медијима и јавности, а наглашавано је и недавно као српска реакција на обележавање 70. годишњице Кинеске комунистичке партије. Термин „челично пријатељство” први пут је употребио бивши амбасадор Кине у Србији - Ли. ${ }^{6}$ Истраживање афир-

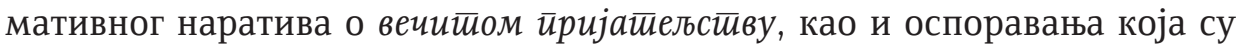
у штампи пропраћена насловима колико кошй а и ga ли је реч о личним и йарйијским ояносима или ояносима између држава и/или нароgа. За сада је јасно да се говори о пријатељству држава, што је разлика у наративу ако се пореди са „француско-српским вечитим пријатељством" (Kolaković, 2018, str. 97), али садржи компоненте стварања термина који је у билатералним односима две земље остао и преживљавао нестабилне периоде дипломатских односа, након којих је омогућавао приближавања. Код стварања ових наратива у контексту изградње слике другога јесте да је граде људи, њихови контакти и везе, при чему су, поред личних и пословних (економских) које су у контексту челичног пријатељства изражене, битне и научне и културне. Садржај наратива челичної

4 Изградња Пупиновог моста (укупне вредности 170 милиона евра, радила је кинеска корпорација за путеве и мостове ЦРБЦ, а финансирала Ексим банка са позајмицом од 144,5 милиона евра, каматном стопом 3\%), посета кинеског председника Србији 2016. године, изградња железничке пруге ка Будимпешти, положај Србије на кинеском Путу свиле, деоница Коридора 11, куповина железаре у Смедереву (Хестил), куповина РТБ Бора (ЗиЂин) само су део економског присуства Кине у Србији.

5 Nevena Bogdanović, „Srbija i Kina: Diplomatija vakcina”, Radio Slobodna Evropa, 29. januar 2021. https://www.slobodnaevropa.org/a/srbija-i-kina-diplomatija-vakcina-/31074774.html (27.08.2021.)

Ognjen Zorić, „Čelično prijateljstvo Srbije i Kine”, Radio Slobodna Evropa, 15. novembar 2018. https://www.slobodnaevropa.org/a/celicno-prijateljstvo-srbije-i-kine/29602462.html (27.08.2021.) 


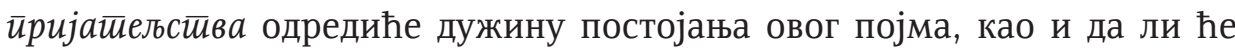
бити јача или слабија везивна компонента дипломатије и стварања позитивних представа о Кини међу Србима.

\section{ЛИТЕРАТУРА}

1. Арежина, С. (2018). Кина у Евройи. Београд: Службени гласник.

2. Благојевић, Г. (2009). Савремени стереотипи Срба о Кинезима у Београду: Када кажеш Кина, мислим Блок 70 или. Зборник Матииие срйске за gрушиивене науке, 128, 47-61.

3. Бредов, А. (1908). Међу боксерима: приповетке из Кине. Нови Сад: Књижарница А. Пајевић.

4. Велимировић, М. (1930). Кроз Кину: йуйойис. Београд: С. Б. Цвијановић.

5. Goldsworthy, V. (1998). Inventing Ruritania. The Imperialism of the Imagination. New Haven and London: Yale University Press.

6. Derrida, J. (1992). The Other Heading: Reflections on Today's Europe. Indiana: Indiana University Press.

7. Динић, Ј. и Лазић, Д. (1970). Нароgна Рейублика Кина: кониейиије о соиијалистииком развоју и йолитиика у међунарояним ояносима. Београд: Институт за међународни раднички покрет.

8. Ђорђевић, J. (1937). Савремена Кина као gржава. Београд: Француско-српска књижара А. Поповића.

9. Јовановић, М. (1894). Тамо амо йо Исииоку. Св. 1: ириее Милана Јовановића (Vol. 16). Београд: Српска књижевна задруга.

10. Јовановић, М. (1895). Тамо амо йо Истиоку. Св. 2: ириее Милана Јовановића (Vol. 25). Београд: Српска књижевна задруга.

11. Kolaković, A. (2018). La France et la Grande Guerre danas la memoire serbe. Srpska politička misao, 83-106.

12. Lyotard, J-F. (1984). The Postmodern Condition: A Report on Knowledge. Minneapolis: University of Minnesota Press.

13. Махин, Ф. (1939). Кина у йламену: савремени ирроблеми Делекоі исйока. Београд: Књижара Косте Јов. Михаиловића.

14. Nors, D. (1999). Balkanski mit. Pitanja identiteta i modernosti. Beograd: Geopoetika.

15. Петковић, Ж. (1937). Кина. Београд: Ж. Маџаревић.

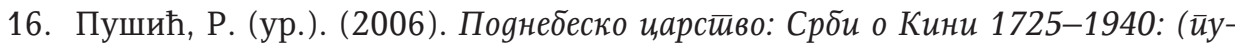
йойиси и илании). Београд: Чигоја штампа. 
17. Радек, К. (1926). Револуција у Кини. Београд: Модерна штампарија Војислава Ненадића.

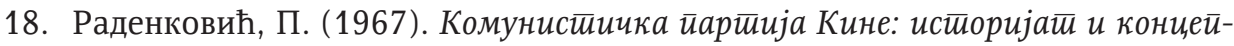
uије. Београд: Наше теме.

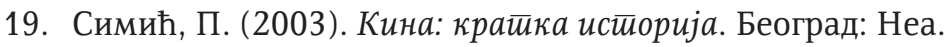

20. Смедли, А. (1940). Кина. Београд: Савремена књига.

21. Станишић, С. (1905). Пуйниике ириее: сибирском железнииом на Далеки истиок (Маниурија - Кина). Велики Бечкерек: Штампарија Свет. Грчића и сина.

22. Стојановић, Т. (1999). Поїлеgинанас, Васина Друі̄ō̄a. Београд: Еqуилибриум.

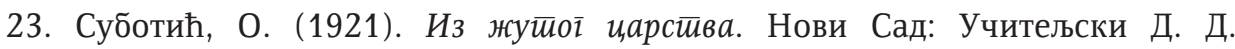
Натошевић.

24. Теслић, В. (1953). Кинеска револуиија и Москва. Београд: Рад.

25. Тодоров, Ц. (1994). Мu u gруїu. Београд: Библиотека XX век.

26. Траиловић, Д. (2018). Политичко-економске и безбедносне алтернативе Србије у очима њених грађана. Политиика националне безбеgностии, 2, 41-56.

27. Траиловић, Д. (2019). Уйииаји међунаровних иинилаиа на еитнике сукобе y Нароgној Рейублиนи Кини. Београд: Факултет политичких наука. https:// fedorabg.bg.ac.rs/fedora/get/o:20813/bdef:Asset/view (22.08.2021.)

28. Цедунг, М. (1968). Кинеска револуиија: Из изабраних gела. Београд: Савремена администрација.

29. Cedung, M. (1972). Citati predsednika Mao Ce Tunga. Peking: Izdavačko preduzeće literature na stranim jezicima.

30. Чавошки, J. (2006). Заборављена епизода: Југословенско-кинески односи 1947. године. Токови истиорије, 4, 183-199.

31. Чавошки, J. (2008). Мао Цедунг, интелектуалци и потреси у комунистичком свету 1956-1957. Токови истиорије. 1/2, 113-136.

32. Чавошки, J. (2013). Почеци дипломатских односа Југославије и Кине и успостављање југословенско-кинеских дипломатских односа 1954-1955. Два века моgерне срйске gийломайије. Београд: Балканолошки институт, Институт за европске студије, 285-301.

33. Чугујев, Т. К. и Ванг, Ш. (1939). Нароga йросвет̄а у Кини. Београд: Милош Б. Јанковић. 


\title{
Aleksandra Kolaković
}

\section{SERBIA'S PERCEPTION OF CHINA: FROM MAO ZEDONG TO THE STEEL FRIENDSHIP}

\begin{abstract}
The paper draws on authentic texts (books, the press and other publications) and current literature to investigate who constructs 'the image of the other', for what purpose and in what way in order to analyze how the perception of China changed in Serbia from creation of the modern Serbian state until the $21^{\text {st }}$ century, when the "steel friendship" narrative emerged. Public opinion polls conducted between 2015 and 2019 by the Institute for Political Studies are also used to explain how China is currently perceived. The paper outlines the image of China among the Serbian people and provides its historical background. It also describes the transfer of ideas in order to encourage researchers to give more attention to these kinds of analyses as they can simultaneously shed light on the history of the diplomatic relations between China and Serbia (formerly Yugoslavia) and help predict how these bilateral relations will develop in the future.
\end{abstract}

Keywords:

China, Chinese people, Serbia, the Serbian people, image of the other, "steel friendship". 